\title{
Phages from Genus Bruynoghevirus and Phage Therapy: Pseudomonas Phage Delta Case
}

\author{
Petar Knezevic ${ }^{1, *}$, Aleksandra Petrovic Fabijan ${ }^{1} \oplus$, Damir Gavric ${ }^{1}$, Jovana Pejic ${ }^{1}$, Zsolt Doffkay ${ }^{2}$ and \\ Gábor Rakhely ${ }^{2}$ (D) \\ 1 Department of Biology and Ecology, Faculty of Sciences, University of Novi Sad, Trg Dositeja Obradovica 3, \\ 21000 Novi Sad, Serbia; aleksandra.petrovic@dbe.uns.ac.rs (A.P.F.); damir.gavric@dbe.uns.ac.rs (D.G.); \\ jovana.pejic@dbe.uns.ac.rs (J.P.) \\ 2 Department of Biotechnology, University of Szeged, Temesvari krt. 62, H-6726 Szeged, Hungary; \\ zsolt.doffkay@bio.u-szeged.hu (Z.D.); rakhely@brc.hu (G.R.) \\ * Correspondence: petar.knezevic@dbe.uns.ac.rs; Tel.: +381-21-485-2685
}

check for updates

Citation: Knezevic, P.; Petrovic Fabijan, A.; Gavric, D.; Pejic, J.; Doffkay, Z.; Rakhely, G. Phages from Genus Bruynoghevirus and Phage Therapy: Pseudomonas Phage Delta Case. Viruses 2021, 13, 1965. https://doi.org/10.3390/v13101965

Academic Editor: Mikael Skurnik

Received: 16 September 2021

Accepted: 23 September 2021

Published: 30 September 2021

Publisher's Note: MDPI stays neutral with regard to jurisdictional claims in published maps and institutional affiliations.

Copyright: (c) 2021 by the authors. Licensee MDPI, Basel, Switzerland. This article is an open access article distributed under the terms and conditions of the Creative Commons Attribution (CC BY) license (https:/ / creativecommons.org/licenses/by/ $4.0 /)$.

\begin{abstract}
The applicability and safety of bacteriophage Delta as a potential anti-Pseudomonas aeruginosa agent belonging to genus Bruynoghevirus (family Podoviridae) was characterised. Phage Delta belongs to the species Pseudomonas virus PaP3, which has been described as a temperate, with cos sites at the end of the genome. The phage Delta possesses a genome of 45,970 bp that encodes tRNA for proline (Pro), aspartic acid (Asp) and asparagine (Asn) and does not encode any known protein involved in lysogeny formation or persistence. Analysis showed that phage Delta has $182 \mathrm{bp}$ direct terminal repeats at the end of genome and lysogeny was confirmed, neither upon infection at low nor at high multiplicity of infection (MOI). The turbid plaques that appear on certain host lawns can result from bacteriophage insensitive mutants that occur with higher frequency $\left(10^{-4}\right)$. In silico analysis showed that the genome of Delta phage does not encode any known bacterial toxin or virulence factor, determinants of antibiotic resistance and known human allergens. Based on the broad host range and high lytic activity against planktonic and biofilm cells, phage Delta represents a promising candidate for phage therapy.
\end{abstract}

Keywords: Pseudomonas phage Delta; Pseudomonas virus PaP3; genome ends; bacteriophage insensitive mutants (BIM); bacterial virulence factors; antibiotic resistance genes; human allergens; therapeutic phage selection

\section{Introduction}

Bacteriophages are potential therapeutic agents against multidrug and pandrug resistant bacteria which are used throughout the world [1]. One of the major problems of phage application as antibacterial agents in the past was the incomprehension of bacteriophage biology [2]. The first prerequisite that must be fulfilled before consideration of a phage as a therapy candidate is its obligatorily lytic nature and good lytic efficacy. Temperate phages can integrate their genome into bacterial DNA, and by an imprecise excision during induction (i.e., initiation of a lytic cycle), they can excise bacterial DNA and transfer it into a new bacterial host through specialised transduction [3]. Some of these genes can contribute to the virulence or antibiotic resistance of infected bacteria. Both obligatorily lytic and temperate phages can be responsible for generalised transduction, which occurs during phage DNA packaging into procapsids. Sometimes bacterial DNA is packaged into viral particles, and frequency of this phenomenon primarily depends on the DNA packaging mechanism, which is the most prominent in phages that use the head-full mechanism [4]. In this context, careful phage selection should prevent the transfer of genes encoding virulence factors, human/animal allergens or genes responsible for bacterial resistance to antibiotics [5-8]. Some phages encode proteins involved in their own life cycle, which also act as eukaryotic toxins or allergens; the best-known example is Vibrio phage 
CTXphi, whose zonula occludens toxin (Zot) is involved in phage extrusion [9]. So far, many phages have been described, and their genomes were sequenced, including phages of Pseudomonas aeruginosa. However, even today, beside a lot of information available, crucial characteristics (e.g., phage temperate or obligatorily lytic nature) are not taken into account during selection for in vivo studies and clinical trials.

Pseudomonas virus PaP3 (Viruses; Duplodnaviria; Heunggongvirae; Uroviricota; Caudoviricetes; Caudovirales; Podoviridae; Bruynoghevirus) has been described originally by Tan et al. [10], and beside the type strain Pseudomonas phage PaP3, additional strains have been described later. These phages share phenotypic characteristics: morphotype $\mathrm{C} 1$, with short tail; broad lytic activity against various strains of $P$. aeruginosa and high in vitro lytic efficacy. It is interesting to point out that a phage belonging to genus the Bruynoghevirus is a part of a commercial preparation for human application (e.g., Intesti-bacteriophage, Georgia) [11]. However, some properties important for the phage therapeutic application have not yet been described, including involvement in production of toxins, allergens or antibiotic resistance factors. On the other hand, some published data are controversial; for instance, Pseudomonas virus PaP3 is described as a temperate phage with cohesive ends (cos) [10], while Pseudomonas virus Luz24, was described as an obligatorily lytic phage with direct terminal repeats (DTR), lacking the cos site [12].

The study aimed to examine genome of phage Delta, a new strain of species Pseudomonas virus $\mathrm{PaP} 3$, and other properties important from the aspect of phage therapy, by determining the phage integrative properties, genome ends and potential presence of genes for bacterial toxins, antibiotic resistance and known human allergens. Thus, here we elucidated phage Delta safety for therapeutical application.

\section{Materials and Methods}

\subsection{Phage Preparation}

The previously isolated Pseudomonas phage Delta [13] was multiplied using original host Pseudomonas aeruginosa strain PA-4U, precipitated in PEG6000 and $\mathrm{NaCl}$, and purified in $\mathrm{CsCl}$ by density ultracentrifugation, as described previously [13,14]. The phage suspension was dialyzed and further treated with DNase and RNase. The purified phage suspension was used for all experiments.

\subsection{DNA Sequencing}

DNA was isolated from virions using standard phenol-chloroform procedure [15]. The isolated DNA was treated with RNase and re-precipitated. Whole genome sequencing of phages was performed using Illumina technology, while de novo assembly of sequenced fragments was carried out by CLC Genomics Workbench 6.5 software and Mira 4.

\subsection{Phage Delta Genome Analysis}

Open reading frames (ORF) in phage Delta genome were predicted using GenemarkS [16] and MyRast [17]. The genomic DNA was compared using BLASTN algorithm with other related strains and species of genus Bruynoghevirus, as well as from other related genera (Krylovvirus, Vicosavirus and Bjornvirus). Phages of the same species share $>95 \%$ DNA similarity (identity $\times$ query coverage) and phage exemplars belonging to the same species are considered phage strains [18].

The whole genome sequences of bacteriophages were obtained from GenBank and used for phylogenetic analysis (listed in Table 1). Phage phylogeny was examined using MUSCLE alignment and phylogenetic tree was constructed using MEGAX [19]. The major capsid protein and terminase amino-acid sequences were compared among the phages using ClustalW alignment and Maximum Likelihood method with Kimura 2-parameter model and bootstrap value 1000 [20].

The presence of tRNA genes in the genomes were predicted for phage Delta and (re)checked for other related phages using ARAGORN (http:/ / mbio-serv2.mbioekol.lu. se/ARAGORN/, accessed on 6 June 2016) [21] and tRNAScanSE Search Server (http:/ / 
lowelab.ucsc.edu/tRNAscan-SE/, accessed on 16 May 2016) [22]. BLASTN algorithm was used to determine PaP3 related prophage existence in sequenced genomes of Pseudomonas strains available in GenBank. The lifestyle of the phages was predicted using the PHACTS algorithm (http:/ / www.phantome.org/PHACTS/, accessed on 18 July 2016) [23].

\subsection{Lysogeny Formation}

To examine possibility of phage Delta integration into bacterial DNA, phages and sensitive P. aeruginosa PAO1 strain were incubated for $24 \mathrm{~h}$ at $37^{\circ} \mathrm{C}$ at MOI 0.1 and 10 . The mixture was then plated on a Luria-Bertani medium to obtain colonies of survived bacterial cells. Several colonies were picked up, transferred onto new medium and subsequently their DNA was isolated using GeneJET Genomic DNA Purification Kit (Thermo Fisher Scientific, Vilnius, Lithuania). The extracted DNA was digested using FastDigest endonuclease SmaI (Thermo Fisher Scientific, Inc., Waltham, MA, USA), which cannot cut phage Delta DNA but can cut bacterial DNA, generating many small-sized fragments. In parallel, DNA of non-infected bacteria was used as a control of enzyme activity and absence of phage Delta DNA in the bacterial genome, while phage DNA was used as a negative control of enzyme activity (i.e., control of phage DNA integrity after SmaI treatment). DNA fragments were visualised on $0.7 \%$ agarose gels with ethidium bromide under UV light and documented (BioDoc Analyse, Biometra, Germany).

\subsection{Bacteriophage Insensitive Mutants (BIM)}

The incidence of phage Delta insensitive mutants of $P$. aeruginosa was determined using a modified method by O'Flynn et al. (2006) [24]. Two bacterial strains were used for the experiment: PA-4U, a urine isolate UB-5296 and ear-infection strain OB-7025 [13]. To obtain MOI $=10,1 \times 10^{10} \mathrm{CFUmL}^{-1}$ of bacteria and $1 \times 10^{11} \mathrm{PFUmL}^{-1}$ of bacteriophage were added. Based on the Poisson distribution, MOI of 10 gives $100 \%$ infection in a culture, so only BIM can survive. The mixture of phage and bacteria was incubated at $37^{\circ} \mathrm{C}$ for $15 \mathrm{~min}$ and then various volumes were poured over solid LB medium. The plates were incubated at $37^{\circ} \mathrm{C}$, and the number of survived cells was determined by counting colonies after 24 and $48 \mathrm{~h}$. The mean colony numbers and standard deviations were calculated from three independent experiments with three replicates. The frequency of occurrence of mutants was calculated as the ratio of the number of grown colonies and the initial number of bacteria per milliliter. Phage resistance and absence of (pro)phage genome in cells were additionally performed.

\subsection{Determination of Phage Genome Ends}

The presence of cos sites at the ends of phage Delta genomic DNA was examined by the coherence of the two terminal restriction fragments [25]. For this purpose, DNA was restricted by BamHI that gives a few well distinctive bands. The restricted DNA was heated at $75{ }^{\circ} \mathrm{C} 15 \mathrm{~min}$ and then cooled either slowly at room temperature or rapidly on ice. The slow cooling conditions lead to annealing of cohesive ends, visible on an agarose gel as an appearance of a larger size band, with loose or fainting of two smaller sized bands. Under fast cooling conditions, the two terminal bands do not have time to anneal, giving no change of the original RFLP pattern. The products were analysed by $1.0 \%$ agarose gel electrophoresis detected with ethidium bromide under UV light and documented (BioDoc Analyse, Biometra, Göttingen, Germany).

\subsection{Potential Virulence Factors}

Potential virulence factors encoded by phages were examined by BLASTP algorithm against a virulence factor database (VFDB, http:/ / www.mgc.ac.cn/VFs/main.htm, accessed on 17 July 2016) [26]. Hits with more than $70 \%$ coverage and $30 \%$ identity were considered as positive results or if $\mathrm{E}<10^{-3}$. 


\subsection{Antibiotic Resistance Genes}

Potential antibiotic resistance genes in the genome of Pseudomonas virus PaP3 were examined by BLASTP against the resistance gene database, with setup value $>10 \%$ identity and $\mathrm{E}<10^{-3}$ (https:/ / card.mcmaster.ca/analyze/blast, accessed in 5 July 2016) [27].

\subsection{Potential Allergens}

The phage proteins were analysed to identify potential human allergenic proteins, using tools available at http:/ / www.allergenonline.com (accessed on 15 July 2016) from the Food Allergy Research [28]. For the full-length alignments by BLASTP a possible cross-reactivity was considered if $\mathrm{E}<10^{-3}$. An additional method, using a sliding window of 80 amino acid segments of each protein, was also carried out to confirm significance. The best identities of phage proteins and allergens greater than $35 \%$ and $\mathrm{E}<10^{-3}$ were considered significant [29].

\section{Results and Discussion}

Phage Delta morphology corresponds to other strains of the species Pseudomonas virus PaP3 with the head diameter of approx. $60 \mathrm{~nm}$ and morphotype $\mathrm{C} 1$ [25]. The genome nucleotide sequence was deposited in the GenBank database under accession number MG432151, and it consists of 45,970 bp with GC\% 52.2 (Table 1). Three tRNA were detected: tRNA- proline (Pro), asparagine (Asn) and aspartic acid (Asp), as in other strains of Pseudomonas virus $\mathrm{PaP} 3$, with an exception of $\mathrm{PaP} 3$ phage that encodes tRNA for tyrosine (Tyr) in addition. The genome encodes 69 proteins and approximately one third of genes are in opposite orientation in comparison to the rest of the genome. The genome comprises early genes, genes for DNA synthesis/replication, virion assembly and host lysis but lacks integrase, repressor and known genes involved in prophage persistence.

The phylogenetic analyses based on amino-acid sequences of major head protein (Figure 1A) and terminase (Figure 1B) showed relations of phage Delta to members of the genus Bruynoghevirus from the family Podoviridae, but also to genera Krylovvirus, Vicosavirus and Bjornvirus. Analyses of DNA similarity of phage Delta sequence confirmed that this phage belongs to the species Pseudomonas virus Pap3, and that there are nine different strains in total, along with phage Delta, isolated throughout the world that belong to this species (Table 1).

The bacteriophage Delta has broad lytic activity against many P. aeruginosa strains (72.7\% from a culture collection) [13] and has prominent lytic activity against both planktonic and biofilm cells [14]. Even though the phage is a promising candidate for phage therapy, its close relative, phage $\mathrm{PaP} 3$, was proven to be temperate with genome containing cos ends. This characteristic is not desirable from the aspect of phage application in therapy, therefore the phage Delta was further examined. 
Table 1. Characteristics of Pseudomonas phage Delta and related (pro)phages.

\begin{tabular}{|c|c|c|c|c|c|c|c|c|c|c|c|c|}
\hline $\begin{array}{l}\text { Genus in } \\
\text { Family } \\
\text { Podoviridae }\end{array}$ & Species & $\begin{array}{l}\text { Strain }{ }^{1} \\
\text { Access. No. }\end{array}$ & $\begin{array}{c}\text { Genome } \\
\text { (bp)/No. CDS }\end{array}$ & Origin (Country) & Plaques (mm) & $\begin{array}{c}\text { Head } \\
\text { Diameter (nm) }\end{array}$ & tRNA & $\begin{array}{l}\text { Similarity to } \\
\text { Delta (\%) }\end{array}$ & $\mathrm{HflK} / \mathrm{C} / \cos ^{1}$ & $\begin{array}{l}\text { Integrat. } \\
\text { Tolaasii/PaP3 }\end{array}$ & $\begin{array}{c}\text { Phage } \\
\text { Lifestyle }^{2}\end{array}$ & Ref. \\
\hline \multirow{16}{*}{ Bruynoghevirus } & \multirow{8}{*}{$\begin{array}{l}\text { Pseudomonas } \\
\text { virus PaP3 }\end{array}$} & $\begin{array}{c}\text { PaP3 } \\
\text { AY078382 } \\
\end{array}$ & $45,503 / 72$ & $\begin{array}{c}\text { Hospital } \\
\text { sewage/China }\end{array}$ & Turbid (1.5) & 55 & $\begin{array}{l}\text { Asn, Asp, Pro, } \\
\text { Tyr }\end{array}$ & 96.2 & $N / Y$ & $N / Y$ & $0.51 \pm 0.04 \mathrm{~L}$ & [10] \\
\hline & & $\begin{array}{l}\text { P2-10_Or1 } \\
\text { HF543949 }\end{array}$ & $44,030 / 71$ & $\begin{array}{c}\text { Eliava } \\
\text { "Pyophage"/Georgia }\end{array}$ & N. A. & $58-60$ & Asn, Asp, Pro & 96.8 & $N / Y$ & $N / Y$ & $0.52 \pm 0.05 \mathrm{~L}$ & [30] \\
\hline & & $\begin{array}{l}\text { MR299-2 } \\
\text { JN254801 }\end{array}$ & $44,789 / 68$ & $\begin{array}{l}\text { Sewage from water } \\
\text { treatment plant }\end{array}$ & N. A. & $40-60$ & Asn, Asp, Pro & 96.6 & $N / Y$ & $N / Y$ & $0.53 \pm 0.03 \mathrm{~L}^{*}$ & [31] \\
\hline & & $\begin{array}{c}\text { otherone } \\
\text { MT119373.1 }\end{array}$ & $44,930 / 67$ & Wastewater & N.A. & N.A. & Asn, Asp, Pro & 96.9 & $N / Y$ & $N / Y$ & $0.53 \pm 0.04 \mathrm{~L}$ & [32] \\
\hline & & $\begin{array}{c}\text { Clash } \\
\text { MT119362.1 }\end{array}$ & $44,912 / 67$ & Wastewater & N.A. & N.A. & Asn, Asp, Pro & 96.8 & $N / Y$ & $N / Y$ & $0.53 \pm 0.06 \mathrm{~L}$ & [32] \\
\hline & & $\begin{array}{c}\text { Delta } \\
\text { MG432151.1 }\end{array}$ & $45,970 / 69$ & $\begin{array}{c}\text { Municipal } \\
\text { wastewater/Serbia }\end{array}$ & $\begin{array}{c}\text { Clear/turbid } \\
(2.5-5.0)\end{array}$ & 63 & Asn, Asp, Pro & 100.0 & $N / Y$ & $N / Y$ & $0.54 \pm 0.03 \mathrm{~L}^{*}$ & This ref. \\
\hline & & $\begin{array}{l}\text { vB_PaeP_fHoPae04 } \\
\text { MW329986.1 }\end{array}$ & $45,491 / 70$ & $\begin{array}{l}\text { Hospital } \\
\text { wastewater, } \\
\text { Finland }\end{array}$ & N.A. & N.A. & Asn, Asp, Pro & 96.4 & $N / Y$ & $N / Y$ & $0.53 \pm 0.03 \mathrm{~L}$ & [33] \\
\hline & & $\begin{array}{c}\text { Epa 1 } \\
\text { MT108723.1 } \\
\end{array}$ & $45,230 / 67$ & N.A. & N.A. & N.A. & Asn, Asp, Pro & 94.3 & $N / Y$ & $N / Y$ & $0.52 \pm 0.04 \mathrm{~L}$ & N.A. \\
\hline & $\begin{array}{l}\text { Pseudomonas } \\
\text { virus CHU }\end{array}$ & $\begin{array}{c}\text { CHU } \\
\text { KP233880.1 }\end{array}$ & $45,626 / 76$ & Pond/Russia & Variable & N.A. & Pro, Asp, Asn & 92.1 & $N / Y$ & $\mathrm{~N} / \mathrm{Y}$ & $0.54 \pm 0.06 \mathrm{~L}$ & [34] \\
\hline & $\begin{array}{l}\text { Pseudomonas } \\
\text { virus Pa223 }\end{array}$ & $\begin{array}{c}\text { Pa223 } \\
\text { MK837012.1 } \\
\end{array}$ & $45,703 / 71$ & N.A. & N.A. & N.A. & Asn ${ }^{*}, \operatorname{Tyr}{ }^{*}$, Pro * & 78.4 & $\mathrm{Y} / \mathrm{Y}$ & $\mathrm{N} / \mathrm{Y}(1)^{*}$ & $0.58 \pm 0.05 \mathrm{~L}^{*}$ & [35] \\
\hline & $\begin{array}{l}\text { Pseudomonas } \\
\text { virus Luz24 }\end{array}$ & $\begin{array}{c}\text { Luz24 } \\
\text { AM910650.1 }\end{array}$ & $45,503 / 68$ & $\begin{array}{c}\text { Hospital } \\
\text { sewage/Belgium }\end{array}$ & $\begin{array}{c}\text { Clear/turbid } \\
(1.0-5.0)\end{array}$ & 63 & Asn ${ }^{*}, \operatorname{Tyr}^{*}, \operatorname{Pro}^{*}$ & 74.3 & $\mathrm{~N} / \mathrm{N}$ & N/Y (1) & $0.66 \pm 0.12 \mathrm{~L}^{*}$ & [12] \\
\hline & $\begin{array}{l}\text { Pseudomonas } \\
\text { virus Dl54 }\end{array}$ & $\begin{array}{c}\text { DL54 } \\
\text { KR054029.1 }\end{array}$ & $45,673 / 71$ & $\begin{array}{l}\text { crude sewage or } \\
\text { flood water/UK }\end{array}$ & Clear/turbid & 45 & $\mathrm{Ile}^{*}$, Asp *, Pro* & 77.1 & $\mathrm{Y} / \mathrm{Y}$ & N/Y (1) & $0.53 \pm 0.07 \mathrm{~L}$ & [36] \\
\hline & $\begin{array}{c}\text { Pseudomonas } \\
\text { virus } \\
\text { C2-10_Ab22 }\end{array}$ & $\begin{array}{l}\text { C2-10_Ab22 } \\
\text { LN610578.1 }\end{array}$ & $45,808 / 71$ & $\begin{array}{c}\text { Carrefour de } \\
\text { l'Indénié/Ivory } \\
\text { Coast }\end{array}$ & N.A. & N.A. & Pro, Tyr, Asn & 74.8 & $\mathrm{Y} / \mathrm{N}$ & N/Y (1) & $0.55 \pm 0.08 \mathrm{~L}$ & [30] \\
\hline & $\begin{array}{c}\text { Pseudomonas } \\
\text { virus } \\
\text { phiBB-PAA2 }\end{array}$ & $\begin{array}{l}\text { phiBB-PAA2 } \\
\text { KF856712.1 }\end{array}$ & $45,344 / 66$ & $\begin{array}{c}\text { Hospital } \\
\text { sewage/Portugal }\end{array}$ & N.A. & N.A. & Pro, Asp, Ile & 81.8 & $\mathrm{~N} / \mathrm{Y}$ & N/Y (1) & $0.58 \pm 0.06 \mathrm{~L}^{*}$ & [37] \\
\hline & $\begin{array}{l}\text { Pseudomonas } \\
\text { virus Pap4 }\end{array}$ & $\begin{array}{c}\text { Pap4 } \\
\text { KC294142.1 }\end{array}$ & $43,895 * / 70$ & N.A. & $\begin{array}{c}\text { Transparent } \\
(3.0-5.0)\end{array}$ & 50 & No & 75.3 & $\mathrm{Y} / \mathrm{Y}$ & $\mathrm{N} / \mathrm{N}$ & $0.58 \pm 0.05 \mathrm{~L}^{*}$ & [38] \\
\hline & & $\begin{array}{l}\text { phiPAO1-EW } \\
\text { MG589386.1 }\end{array}$ & $46,403 / 71$ & N.A. & N.A. & N.A. & Ile, asp, Pro & 75.5 & $\mathrm{Y} / \mathrm{Y}$ & N/Y (3) & $0.56 \pm 0.05 \mathrm{~L}^{*}$ & N.A. \\
\hline
\end{tabular}


Table 1. Cont.

\begin{tabular}{|c|c|c|c|c|c|c|c|c|c|c|c|c|}
\hline $\begin{array}{c}\text { Genus in } \\
\text { Family } \\
\text { Podoviridae }\end{array}$ & Species & $\begin{array}{c}\text { Strain }{ }^{1} \\
\text { Access. No. }\end{array}$ & $\begin{array}{c}\text { Genome } \\
\text { (bp)/No. CDS }\end{array}$ & Origin (Country) & Plaques (mm) & $\begin{array}{c}\text { Head } \\
\text { Diameter (nm) }\end{array}$ & tRNA & $\begin{array}{l}\text { Similarity to } \\
\text { Delta (\%) }\end{array}$ & $\mathrm{HflK} / \mathrm{C} / \cos ^{1}$ & $\begin{array}{l}\text { Integrat. } \\
\text { Tolaasii/PaP3 }\end{array}$ & $\begin{array}{c}\text { Phage } \\
\text { Lifestyle }^{2}\end{array}$ & Ref. \\
\hline & & $\begin{array}{l}\text { phiPAO1_302 } \\
\text { MG589385.1 }\end{array}$ & $46,093 / 70$ & N.A. & N.A. & N.A. & Pro, Tyr, Asp, Ile & 65.3 & $\mathrm{Y} / \mathrm{Y}$ & N/Y (1) & $0.54 \pm 0.09 \mathrm{~L}$ & N.A. \\
\hline & & $\begin{array}{c}\text { EPa4 } \\
\text { MT118288.1 } \\
\end{array}$ & $45,439 / 53$ & N.A: & N.A. & N.A. & Asn *, Tyr *, Pro * & 64.9 & $\mathrm{Y} / \mathrm{Y}$ & N/Y (1) & $0.56 \pm 0.05 \mathrm{~L}^{*}$ & [40] \\
\hline & & $\begin{array}{c}\text { Pa222 } \\
\text { MK837011.1 }\end{array}$ & $45,770 / 58$ & N.A. & N.A. & N.A. & $\begin{array}{l}\text { Asn *, Asp *, Tyr } \\
\text { *, Pro* }\end{array}$ & 78.4 & $\mathrm{Y} / \mathrm{Y}$ & N/Y (1) & $0.56 \pm 0.06 \mathrm{~L}^{*}$ & [35] \\
\hline & & $\begin{array}{c}\text { Oldone } \\
\text { MT119371.1 }\end{array}$ & $45,313 / 70$ & Wastewater & N.A. & N.A. & $\begin{array}{l}\text { Asn *, Asp *, Tyr } \\
\text { *, Pro* }\end{array}$ & 78.8 & $\mathrm{Y} / \mathrm{Y}$ & N/Y (1) & $0.52 \pm 0.07 \mathrm{~L}$ & [32] \\
\hline & & $\begin{array}{c}\text { U47 } \\
\text { MN562749.1 }\end{array}$ & $43,444 / 68$ & N.A. & N.A. & N.A. & $\begin{array}{c}\text { Asn *, Asp *, Tyr } \\
\text { *, Pro* }\end{array}$ & 78.2 & $\mathrm{Y} / \mathrm{Y}$ & N/Y (1) & $0.59 \pm 0.07 \mathrm{~L}^{*}$ & N.A. \\
\hline & & $\begin{array}{c}\text { Epa 2 } \\
\text { MT108724.1 }\end{array}$ & $43,229 / 51$ & N.A. & N.A. & N.A. & Asn ${ }^{*}, \operatorname{Tyr}{ }^{*}$, Pro * & 78.0 & $N / Y$ & N/Y (1) & $0.53 \pm 0.06 \mathrm{~L}$ & [41] \\
\hline & & $\begin{array}{c}\text { TL } \\
\text { HG518155.1 }\end{array}$ & $45,696 / 65$ & N.A. & $\begin{array}{l}\text { Transparent } \\
\text { turbid, large }\end{array}$ & & Asn ${ }^{*}, \operatorname{Tyr}^{*}, \operatorname{Pro}^{*}$ & 73.3 & $\mathrm{Y} / \mathrm{N}$ & N/Y (1) & $0.55 \pm 0.08 \mathrm{~L}$ & [42] \\
\hline & & $\begin{array}{c}\text { SL4 } \\
\text { MF768469.1 } \\
\end{array}$ & $44,194 / 65$ & $\begin{array}{l}\text { Hospital sewage, } \\
\text { Germany }\end{array}$ & N.A. & 55 & Asn *, Tyr *, Pro * & 76.4 & $\mathrm{Y} / \mathrm{N}$ & N/Y (1) & $0.54 \pm 0.05 \mathrm{~L}$ & [43] \\
\hline Krylovvirus & $\begin{array}{l}\text { Pseudomonas } \\
\text { virus SCZY1 }\end{array}$ & $\begin{array}{c}\text { SCYZ1 } \\
\text { MH518298.3 } \\
\end{array}$ & $47,475 / 62$ & Soil & N.A. & N.A. & Pro* & 2.3 & $\mathrm{Y} / \mathrm{N}$ & $\mathrm{N} / \mathrm{N}$ & $0.51 \pm 0.04 \mathrm{~L}$ & N.A. \\
\hline \multirow{3}{*}{ Vicosavirus } & $\begin{array}{l}\text { Pseudomonas } \\
\text { virus NV1 }\end{array}$ & $\begin{array}{c}\text { NV1 } \\
\text { NC_042107.1 } \\
\end{array}$ & $45,058 / 64$ & $\begin{array}{l}\text { Untreated sewage, } \\
\text { River Thames, UK }\end{array}$ & $\operatorname{Hazy}(<2)$ & & No & 35.0 & $\mathrm{Y} / \mathrm{N}$ & $Y(1) / N$ & $0.52 \pm 0.05 \mathrm{~T}$ & [45] \\
\hline & $\begin{array}{l}\text { Pseudomonas } \\
\text { virus UVF-P2 }\end{array}$ & $\begin{array}{c}\text { UVF-P2 } \\
\text { JX863101 }\end{array}$ & $45,517 / 75$ & $\begin{array}{c}\text { Dairy industry } \\
\text { wastewater, Brazil }\end{array}$ & N.A. & N.A. & No & 34.7 & $\mathrm{Y} / \mathrm{N}$ & $Y(2) / N$ & $0.53 \pm 0.03 \mathrm{~T}$ * & [46] \\
\hline & & $\begin{array}{c}\text { Prophage } \\
\text { CP020369.1 } \\
(6815074 . . \\
6769117)\end{array}$ & $52.973 / 85$ & - & - & - & No & & $\mathrm{Y} / \mathrm{N}$ & $\mathrm{Y} / \mathrm{N}$ & $0.50 \pm 0.04 \mathrm{~T}$ & This ref. \\
\hline Bjornvirus & $\begin{array}{l}\text { Pseudomonas } \\
\text { virus Bjorn }\end{array}$ & $\begin{array}{c}\text { Bjorn } \\
\text { NC_042103.1 }\end{array}$ & $45,936 / 69$ & Plant compost & N.A. & N.A. & No & 20.0 & $\mathrm{~N} / \mathrm{N}$ & $\mathrm{N} / \mathrm{N}$ & $0.53 \pm 0.05 \mathrm{~L}$ & N.A. \\
\hline
\end{tabular}

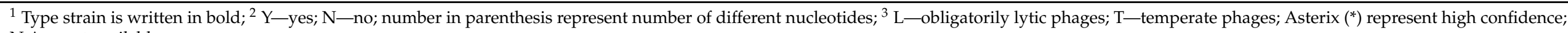
N.A.—not available. 

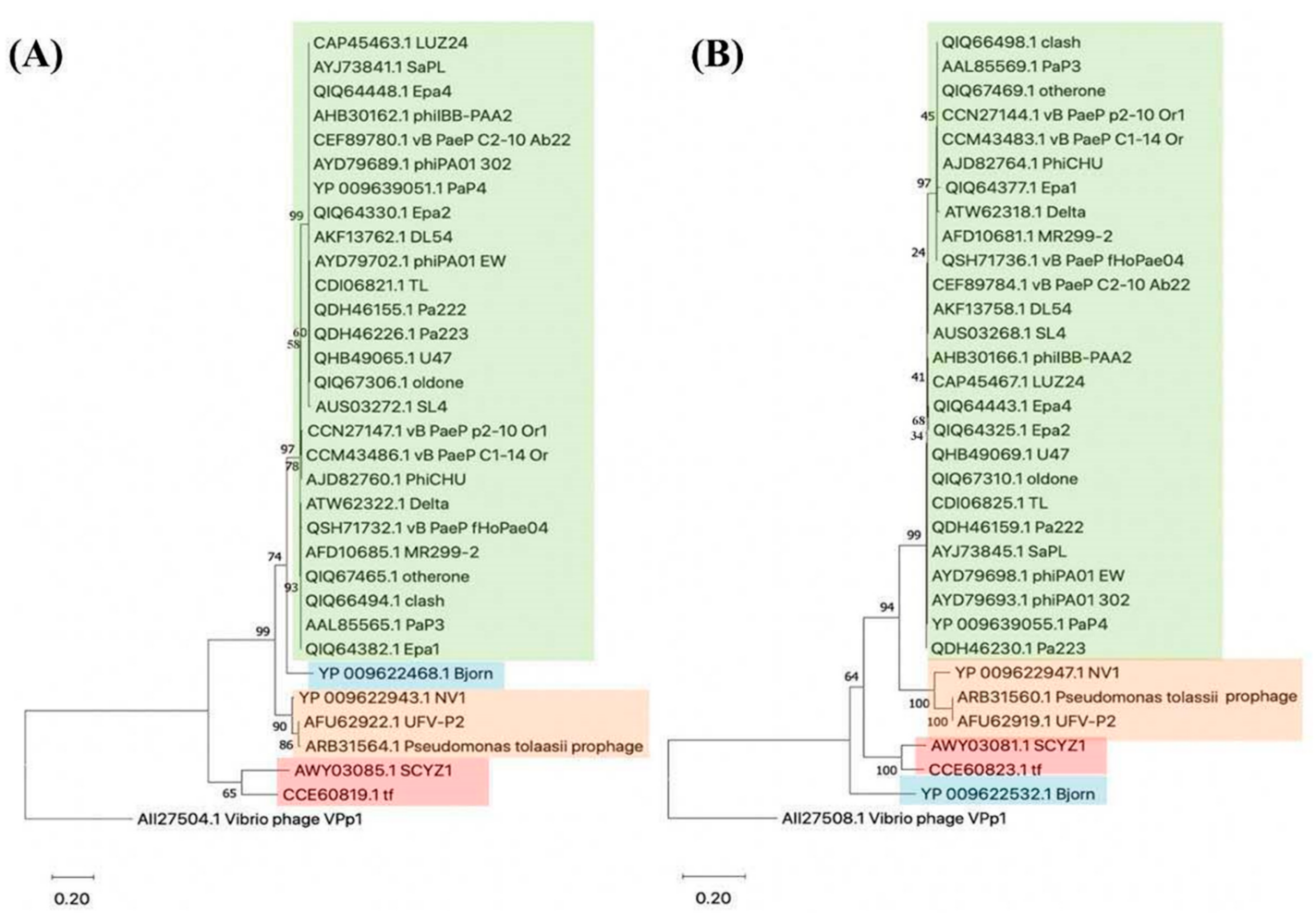

Figure 1. Phylogenetic relationships of phage Delta with other related phages (members of Bruynoghevirus-green, Krylovvirus_red, Vicosavirus_-orange and Bjornvirus_blue) and a prophage of P. tolassii, based on amino-acid sequences of major coat protein (A) and terminase (B). The evolutionary history based on protein sequences was inferred using the Maximum Likelihood method and JTT matrix-based model. Initial trees for the heuristic search were obtained automatically by applying Neighbor-Joining and BioNJ algorithms to a matrix of pairwise distances estimated using a JTT model, and then selecting the topology with superior log likelihood value. Evolutionary analyses were conducted in MEGA X [18] and the percentage of replicate trees in which the associated taxa clustered together in the bootstrap test (1000 replicates) are shown next to the branches [19]. Vibrio phage VPp1 was used as an outlier.

\subsection{Is Bacteriophage Delta Temperate or Obligatorily Lytic Phage?}

With the exception of PaP3, lysogeny formation was not confirmed neither for other strains of species Pseudomonas virus PaP3, nor for other members of the genus Bruynoghevirus.

For PaP3 phage, a sequence in tRNA-Pro was postulated as an att site (GGTCGTAGGTTCGAATCCTAC), and it is in accordance with the fact that tRNAs are generally considered an integration site into the bacterial genome [47]. This 21-mer sequence is present in all strains of the species Pseudomonas virus $\mathrm{PaP} 3$ and phage phiCHU, while almost all other members of the genus Bruynoghevirus have one $A \rightarrow G$ transition in the sequence (Table 1). Even though this difference can be a reason why lysogeny have not been proven in these phages, enzymes involved in recombination/integration usually are not sensitive to the point mutations $[48,49]$.

The phages of peripherally related genera Kryloviirus, Bjornvirus and Vicosavirus also lack this postulated 21-mer att sequence, although Krylovvirus encode tRNA in contrast with other two genera. Only for Vicosavirus lysogeny formation was confirmed, and it seems that att site is different. Namely, when phage Delta genome, or genome of other members of genus Bruynoghevirus are compared to Pseudomonas aeruginosa group (taxid:136841) or Pseudomonas (taxid:287) by BLASTN algorithm in silico, no significant similarities were detected, i.e., $P$. aeruginosa available genomes do not contain sequences similar to these phages (the results are not shown). Among the sequenced genomes of various Pseudomonas species, only one prophage of Pseudomonas tolaasii $2192 \mathrm{~T}$ showed some similarity to phages 
of genus Bruynoghevirus (31.8-36.2\%), and significant similarity with members of genus Vicosavirus (72.1-89.3\%) (Table 1 and Figure 1). The prophage in P. tolaasii genome, related to Bruynoghevirus, neither encode tRNAs nor integrates in the proximity of bacterial tRNA. For instance, prophage integration occurs at a tRNA gene for phages carrying Lambda and P4-like integrases, although they do not encode any tRNA, but only small parts of the gene [50]. However, Bailly-Bechet et al. (2007) [51] indicate that tRNA presence in phage genome is not primarily because of integration but found a significant association between tRNA distribution and codon usage, as phage tRNA codons are simultaneously highly used by the phage genes, being rare in the host genome. They even found that obligatorily lytic phages contain more tRNAs than temperate ones. Just as a comparison, the well-known obligatorily lytic T4 also encodes tRNA [52], without ability to form lysogeny. Thus, the presence of tRNA genes in Bruynoghevirus not necessarily indicates their temperate nature.

The alignment of postulated P. tolaasii $2192 \mathrm{~T}$ prophage ends indicated 42-mer att site with sequence GATGCAGATGGGCGTAATGCTCAACAAGAACCGCGAGGCTGC (Table S1), which is different from postulated att site of PaP3 related phages, and can be found only in Vicosavirus members (Table 1). Accordingly, even if the phages from the genus Bruynoghevirus integrate into the host DNA, the integration site is different than for Vicosavirus.

Furthermore, it seems that some phages of genus Bruynoghevirus contain genes potentially involved in lysogeny formation. For instance, a protein conserved region from SPFH superfamily (stomatin, prohibitin, flotillin and HflK/C) can be detected in some related viruses, including the prophage of $P$. tolaasii (Table 1 ). This protein is frequently annotated as „transposase fusion protein“. The similar protein HflK/C (High frequency of lysogenization) plays a role in the decision making between lysogenic and lytic cycle during Lambda phage infection, antagonising activity of FtsH ATPase/protease, that in E. coli is involved in degradation of Lambda phage cII transcriptional activator, responsible for lysogenisation $[53,54]$. The role of this protein is still not clear, since some phages that are characterised as obligatorily lytic encode it, such as Pseudomonas phage KPP10, PAK-P3, P3-CHA, CHA_P1 and PAK_P5 (Myoviridae), which were successfully used in a cystic fibrosis mice model [55-57]. Thus, phages that encode this protein may be temperate, but its presence in genome is not necessary confirmation of phage temperate nature. Furthermore, the analysis showed that the protein with the conserved SPFH sequence is absent in all strains of Pseudomonas virus PaP3, in phages phiCHU, Luz24, phiBB-PAA2, Epa2 (genus Bruynoghevirus), tf (genus Krylovvirus) and Bjorn (genus Bjornvirus) (Table 1).

Even the lack of phage encoded integration enzymes in other PaP3 related phages does not, however, undoubtedly confirm their obligatorily lytic nature, as prophages can be formed by the activity of corresponding host enzymes [58]. For type strain PaP3, it has been previously demonstrated that upon P. aeruginosa PAO1 infection, the phage genome can be detected as an uncut band by PstI endonuclease in bacterial genomic DNA.

Using the SmaI enzyme, which cannot cut phage Delta genome, we have not confirmed phage genome in bacterial DNA by RFLP upon infection of PAO1 strain (Figure 2II). The absence of the phage DNA band confirmed a lack of its integration or extrachromosomal presence in PAO1, both after infection with low $(\mathrm{MOI}=0.1)$ or high number of virions $(\mathrm{MOI}=10)$. The two different MOIs were used, as it was confirmed that phage lambda, a model for temperate phages, increases the frequency of lysogeny at higher MOI [59]. A study of global transcriptomic analysis of P. aeruginosa PAO1 after infection with PaP3 at MOI = 10 indicate lytic cycle, according to the gene expression and the one-step growth curve, that reach a plateau after $80 \mathrm{~min}$. with burst size approx. 30 [60], resembling to a lytic cycle. Alemayehu et al. (2015) examining phage strain MR299-1 indicated that a previous study calls into question the temperate nature of PaP3 [12], since no site-specific recombinase is encoded up- or downstream of the attP site, and immunity or reactivation of the prophage was not demonstrated. 
(I)

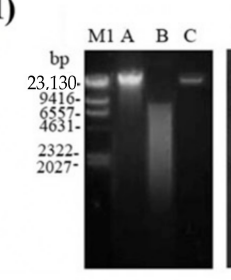

(III)

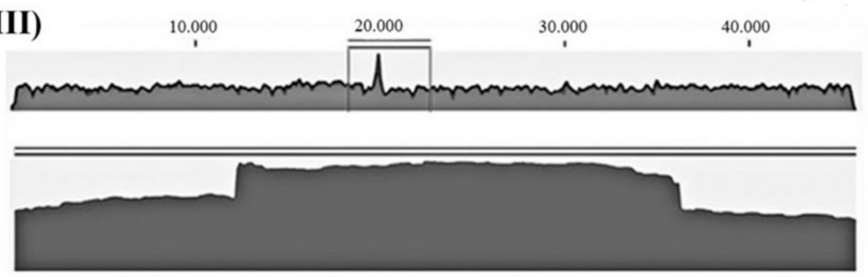

(II)
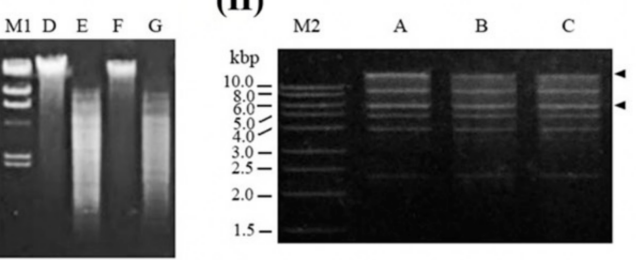

(IV)

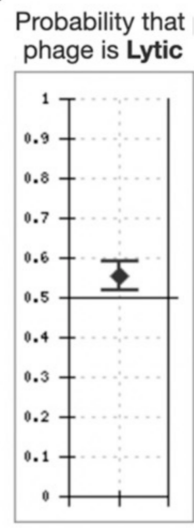

(V)

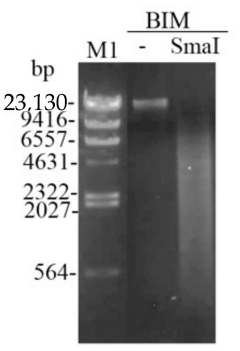

(VI)

(a)

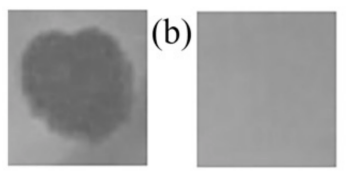

Figure 2. Determination of Pseudomonas phage Delta properties and lifestyle: (I) PAO 1 genomic DNA (A, D and F) was treated with SmaI (B) generating numerous fragments of small size; phage Delta DNA was not cut by SmaI (C); after PAO1 infection at $\mathrm{MOI}=0.1$ phage Delta genome was not detected in PAO1 genome (E), and similar was confirmed when PAO1 was infected at MOI = 10; (II) phage Delta DNA cut by BamHI show no change of restriction pattern after fast and slow cooling, indicating absence of cos site; (III) DNA sequence of phage Delta showed elevation of reads typical for direct terminal repeats; (IV) PHACTS algorithm showed that phage Delta is obligatorily lytic, with high confidence; (V) uncut and SmaI-cut BIM genome showed absence of phage DNA and thus lysogeny; (VI) lysis of sensitive P. aeruginosa lawn by phage Delta (a) and absence of lysis of BIM (b).

The application of PHACTS showed that all strains of species Pseudomonas virus PaP3 are obligatorily lytic, and the findings are confident for strains Delta (Figure 2V) and MR2992, but also for some other species of the genus Bruynoghevirus (Table 1). Similar pertains to Krylovvirus and Bjornvirus, but Vicosavirus members are characterised as temperate (phage UVF-P2 with high confidence). This additionally contributes to the obligatorily lytic nature of Bruynoghevirus members, including phage Delta.

The turbid plaques produced by members of Bruynoghevirus on lawn of certain strains cannot be simply explained by lysogeny formation. To elucidate this phenomenon, the frequency of BIM was determined (Table 2). For original host PA-4U, the frequency of mutant appearance was of order of magnitude $10^{-7}$, and for heterologous strains UB-6259 and OB-7025 frequencies were $10^{-6}$ and $10^{-4}$, respectively. The frequency of BIM was not significantly changed after prolonged incubation. Since phage Delta form turbid plaques on OB-7025 lawn, high frequency of BIM can partially provide an explanation for incomplete lysis and faint plaques formation. The results indicate necessity to examine all host-phage system to determine BIM frequency and to apply measures to decrease BIM frequency (by using phage cocktails, combining phages and antibiotics etc).

Table 2. Frequencies of phage Delta insensitive mutant appearance of various strains.

\begin{tabular}{ccc}
\hline & \multicolumn{2}{c}{ BIM Frequency } \\
\hline Bacterial Host & after $\mathbf{2 4} \mathbf{h}$ & after $\mathbf{4 8 ~ h}$ \\
\hline PA-4U & $3.30 \times 10^{-7} \pm 3.12 \times 10^{-7}$ & $5.38 \times 10^{-7} \pm 5.56 \times 10^{-8}$ \\
UB-2596 & $2.36 \times 10^{-6} \pm 2.74 \times 10^{-7}$ & $5.67 \times 10^{-6} \pm 1.67 \times 10^{-6}$ \\
OB-7025 & $7.95 \times 10^{-4} \pm 3.24 \times 10^{-5}$ & $9.62 \times 10^{-4} \pm 4.12 \times 10^{-5}$ \\
\hline
\end{tabular}

Taking into account the above considerations, it is clear that there is no evidence that strains of the species Pseudomonas virus Pap3 are temperate. Even if these phages are temperate, their lysogeny is extremely unstable or integration is very rare. 


\subsection{Is Pseudomonas Phage PaP3 Prone to Generalised Transduction?}

There are several types of phage termini: cohesive ends (5'- or $3^{\prime}$-single-strand extensions), circularly permuted direct terminal repeats, short or long exact direct terminal repeats (DTR), terminal host DNA sequences or covalently bound terminal proteins. A particular termini type is a result of a phage packaging strategy: $5^{\prime} \cos$ (e.g., Lambda phage), $3^{\prime} \cos$ (e.g., phage HK97), headful with a pac site (e.g., phage P1), headful without a pac site (e.g., phage T4), DTR (e.g., phage T7) and host fragment at genome ends (e.g., phage $\mathrm{Mu})[25,61]$. The bacteriophages that pack DNA by means of headful mechanism can more frequently form defective virions, carrying parts of bacterial DNA, being prone to generalised transduction [61,62]. This is not a desirable property for a phage intended for therapy, since phages can transfer genes involved in bacterial virulence. Experiments with phage Delta genomic DNA restriction pattern with BamHI showed no difference if samples heated to $75^{\circ} \mathrm{C}$ and then cooled quickly or slowly (Figure 2III), indicating the absence of $\cos$ site. A 20-mer sequence postulated as a $\cos$ in PaP3 (5'-GCCGGCCCCTTTCCGCGTTA$\left.3^{\prime}\right)$ [10] is present in most phage genomes that encode tRNA-Pro (Table 1), identical or with one base changed. The analysis of the phage Delta genome sequence did not confirm cos genome ends. Still, it revealed presence of $182 \mathrm{bp}$ long DTR in the genome assembly (Figure 2IV), which is obviously as twice as the average sequence coverage [62].

It is believed that mechanism of packaging and type of termini can be successfully predicted from amino-acid sequence of large terminase subunits, which is quite conserved among the most tailed-phage proteins [63]. Previous analyses of phage LUZ24 and PaP3 terminases are strongly related to the terminase of phage P22, which catalyses the headful packaging, leading to both terminal redundancy and circular permutations [12,64]. However, some studies showed that terminase amino-acid sequence is not very reliable in determination of packaging mechanism [65], which is confirmed for Luz24, as well as phage Delta, that both have long direct terminal repeats (182 and $184 \mathrm{bp}$, respectively). Summarising our results on genome ends examination, it is clear that phage Delta has a packaging mechanism similar to phage T7, being less prone to generalised transduction than phages with a headful packaging strategy. Finally, even if some phage Delta related phages have $\cos$, they also rarely mediate in horizontal transfer by generalised transduction as phages with DTRs [66].

\subsection{Does the Phage Delta Genome Encode Undesirable Proteins?}

The results of phage protein in silico examination, carried out to find genes for potential virulence factors, antibiotic resistance proteins and allergens, are presented in Supplementary Materials.

Only one protein encoded by members of Pseudomonas virus PaP3 showed some similarity with a bacterial virulence factors-Dot/Icm type IV secretion system effector SidK of Legionella pneumophila subsp. pneumophila, but below cut-off E value. In the phages, this protein is a small terminase subunit and has no conserved domains similar to the virulence factor. Thus, the phages do not encode known bacterial virulence factors.

Analysis of known antibiotic resistance genes showed that almost all members of genus Bruynoghevirus possess a gene similar to B3 class of beta lactamase, i.e., metallo-beta lactamase found in Massilia oculi. Similarly, members of Vicosavirus also encode a protein similar to class A beta lactamase precursor RCP found in Rhodopseudomonas capsulata. However, the observed similarities are not significant, indicating that phages do not carry known antibiotic resistance genes.

It is well known that phages do not cause allergic reactions after application, but since their structural proteins are antigenic $[67,68]$, the potential production of IgE should not be neglected. The full-length BLASTP alignments and 80-mer sliding method showed similarity of $\mathrm{PaP} 3$, phiCHU and UFV-P2 prroteins to $30 \mathrm{kDa}$ salivary gland allergen variant 2 of Aedes aegypti. In addition, ORF 54 of phage PaP4 is significantly similar to collagen alpha-2(I) chain isoform $\mathrm{X} 1$ of Salmo salar, and ORF 53 of phage tf is significantly similar to high molecular weight glutenin subunit 10 of Triticum aestivum. According to the 
FAO/WHO 2001 experts and the Codex Alimentarius Commission (2003), a >35\% identity to an allergen over of any segment of 80 or more amino acids indicates possible crossreactivity. Even though phages are generally safe for application $[69,70]$, if these phages are intended for therapy, further evaluation of IgE reactivity or clinical cross-reactivity may be warranted to test for these potential allergens. In potential clinical trials, all these phages should be used with precautions in individuals allergic to corresponding antigens.

The results indicate that phage Delta proteins show no significant similarity to known bacterial virulence factors, determinants of $P$. aeruginosa resistance to conventional antibiotics and allergens.

\section{Conclusions}

For most Bruynoghevirus members, including phage Delta, there is no evidence of lysogeny formation, and DNA is packaged by the T7 model, indicating lower generalised transduction capacity. The genome of the Delta phage does not encode known virulence factors, antibiotic resistance determinants and allergens. These data, along with high lytic efficacy and broad activity against various strains of P. aeruginosa recommend this phage as a potent anti-Pseudomonas agent. Some shortfalls, such us high frequency of BIM can be overcome by phage cocktail preparation, combination with antibiotics etc. If such thorough analysis of a phage does not confirm undesirable properties, for the therapeutic phages should be applied „presumption of innocence-everyone is considered innocent until proven guilty", i.e., a phage that fulfils criteria for application is considered safe for therapy until proven otherwise.

Supplementary Materials: The following are available online at https:/ / www.mdpi.com/article/ 10.3390/v13101965/s1, Table S1: Predicted PaP3 related prophage in genome of P. tolaasii 2192T using various tools for prophage detection and manually predicted, Table S2: Potential virulence factors, antibiotic resistance related proteins and allergens encoded by phage Delta and other related (pro)phages.

Author Contributions: Conceptualisation, P.K.; investigation and formal analysis P.K., A.P.F., D.G. and J.P.; genome analysis G.R., Z.D.; experimental data analysis and discussion P.K., A.P.F., D.G. and J.P.; writing, P.K. and D.G.; visualisation, P.K.; supervision of the study, P.K.; funding acquisition, P.K. All authors have read and agreed to the published version of the manuscript.

Funding: This study was funded in the frame of PROMIS programme of Science Fund of the Republic of Serbia and its constituent project PHANTER (No. 6066764) and Hungary-Serbia IPA Cross-border Co-operation Programme, project NNAA HUSRB/1203/214/250.

Institutional Review Board Statement: Not applicable.

Informed Consent Statement: Not applicable.

Data Availability Statement: Not applicable.

Conflicts of Interest: The authors declare no conflict of interest.

\section{References}

1. Knezevic, P.; Hoyle, N.S.; Matsuzaki, S.; Gorski, A. Editorial: Advances in Phage Therapy: Present Challenges and Future Perspectives. Front. Microbiol. 2021, 12, 701898. [CrossRef] [PubMed]

2. Summers, W.C. The strange history of phage therapy. Bacteriophage 2012, 2, 130-133. [CrossRef]

3. Zhang, Z.; Kottadiel, V.I.; Vafabakhsh, R.; Dai, L.; Chemla, Y.R.; Ha, T.; Rao, V.B. A Promiscuous DNA Packaging Machine from Bacteriophage T4. PLoS Biol. 2011, 9, e1000592. [CrossRef] [PubMed]

4. Gibson, E.J. Chapter 23. In An Odyssey in Learning and Perception; The MIT Press: Cambridge, MA, USA, 2020; p. 501. [CrossRef]

5. Chen, J.; Novick, R.P. Phage-Mediated Intergeneric Transfer of Toxin Genes. Science 2009, 323, 139-141. [CrossRef]

6. Balcazar, J.L. Bacteriophages as Vehicles for Antibiotic Resistance Genes in the Environment. PLOS Pathog. 2014, 10, e1004219. [CrossRef]

7. James, C.; Davies, E.V.; Fothergill, J.; Walshaw, M.J.; Beale, C.M.; Brockhurst, M.A.; Winstanley, C. Lytic activity by temperate phages of Pseudomonas aeruginosa in long-term cystic fibrosis chronic lung infections. ISME J. 2015, 9, 1391-1398. [CrossRef] 
8. Shousha, A.; Awaiwanont, N.; Sofka, D.; Smulders, F.J.M.; Paulsen, P.; Szostak, M.P.; Humphrey, T.; Hilbert, F. Bacteriophages Isolated from Chicken Meat and the Horizontal Transfer of Antimicrobial Resistance Genes. Appl. Environ. Microbiol. 2015, 81, 4600-4606. [CrossRef]

9. Waldor, M.K.; Mekalanos, J.J. Lysogenic Conversion by a Filamentous Phage Encoding Cholera Toxin. Science 1996, 272, 1910-1914. [CrossRef]

10. Tan, Y.; Zhang, K.; Rao, X.; Jin, X.; Huang, J.; Zhu, J.; Chen, Z.; Hu, X.; Shen, X.; Wang, L.; et al. Whole genome sequencing of a novel temperate bacteriophage ofP. aeruginosa: Evidence of tRNA gene mediating integration of the phage genome into the host bacterial chromosome. Cell. Microbiol. 2006, 9, 479-491. [CrossRef]

11. Zschach, H.; Joensen, K.G.; Lindhard, B.; Lund, O.; Goderdzishvili, M.; Chkonia, I.; Jgenti, G.; Kvatadze, N.; Alavidze, Z.; Kutter, E.M.; et al. What Can We Learn from a Metagenomic Analysis of a Georgian Bacteriophage Cocktail? Viruses 2015, 7, 6570-6589. [CrossRef]

12. Ceyssens, P.-J.; Hertveldt, K.; Ackermann, H.-W.; Noben, J.-P.; Demeke, M.; Volckaert, G.; Lavigne, R. The intron-containing genome of the lytic Pseudomonas phage LUZ24 resembles the temperate phage PaP3. Virology 2008, 377, 233-238. [CrossRef] [PubMed]

13. Knezevic, P.; Kostanjsek, R.; Obreht, D.; Petrovic, O. Isolation of Pseudomonas aeruginosa Specific Phages with Broad Activity Spectra. Curr. Microbiol. 2009, 59, 173-180. [CrossRef] [PubMed]

14. Knezevic, P.; Obreht, D.; Curcin, S.; Petrusic, M.; Aleksic, V.; Kostanjšek, R.; Petrović, O. Phages of Pseudomonas aeruginosa: Response to environmental factors and in vitro ability to inhibit bacterial growth and biofilm formation. J. Appl. Microbiol. 2011, 111, 245-254. [CrossRef]

15. Sambrook, J.; Russell, D. Molecular Cloning: A Laboratory Manual, 3rd ed.; Cold Spring Harbor Laboratory Press: Cold Spring Harbor, NY, USA, 2001.

16. Besemer, J.; Lomsadze, A.; Borodovsky, M. GeneMarkS: A self-training method for prediction of gene starts in microbial genomes. Implications for finding sequence motifs in regulatory regions. Nucleic Acids Res. 2001, 29, 2607-2618. [CrossRef]

17. Aziz, R.K.; Bartels, D.; Best, A.A.; DeJongh, M.; Disz, T.; Edwards, R.A.; Formsma, K.; Gerdes, S.; Glass, E.M.; Kubal, M.; et al. The RAST Server: Rapid Annotations using Subsystems Technology. BMC Genom. 2008, 9, 75. [CrossRef]

18. Adriaenssens, E.; Brister, J.R. How to Name and Classify Your Phage: An Informal Guide. Viruses 2017, 9, 70. [CrossRef]

19. Kumar, S.; Stecher, G.; Li, M.; Knyaz, C.; Tamura, K. MEGA X: Molecular Evolutionary Genetics Analysis across Computing Platforms. Mol. Biol. Evol. 2018, 35, 1547-1549. [CrossRef]

20. Felsenstein, J. Confidence limits on phylogenies: An approach using the bootstrap. Evolution 1985, 39, 783-791. [CrossRef]

21. Laslett, D.; Canback, B. ARAGORN, a program to detect tRNA genes and tmRNA genes in nucleotide sequences. Nucleic Acids Res. 2004, 32, 11-16. [CrossRef]

22. Lowe, T.M.; Chan, P.P. tRNAscan-SE On-line: Integrating search and context for analysis of transfer RNA genes. Nucleic Acids Res. 2016, 44, W54-W57. [CrossRef]

23. McNair, K.; Bailey, B.A.; Edwards, R.A. PHACTS, a computational approach to classifying the lifestyle of phages. Bioinformatics 2012, 28, 614-618. [CrossRef] [PubMed]

24. O'Flynn, G.; Coffey, A.; Fitzgerald, G.; Ross, R. The newly isolated lytic bacteriophages st104a and st104b are highly virulent against Salmonella enterica. J. Appl. Microbiol. 2006, 101, 251-259. [CrossRef]

25. Casjens, S.R.; Gilcrease, E.B. Determining DNA Packaging Strategy by Analysis of the Termini of the Chromosomes in TailedBacteriophage Virions. Stem Cells and Aging 2009, 502, 91-111. [CrossRef]

26. Chen, L.; Zheng, D.; Liu, B.; Yang, J.; Jin, Q. VFDB 2016: Hierarchical and refined dataset for big data analysis-10 years on. Nucleic Acids Res. 2016, 44, D694-D697. [CrossRef] [PubMed]

27. Alcock, B.P.; Raphenya, A.R.; Lau, T.T.Y.; Tsang, K.K.; Bouchard, M.; Edalatmand, A.; Huynh, W.; Nguyen, A.-L.V.; Cheng, A.A.; Liu, S.; et al. CARD 2020: Antibiotic resistome surveillance with the comprehensive antibiotic resistance database. Nucleic Acids Res. 2020, 48, D517-D525. [CrossRef] [PubMed]

28. Aalberse, R.C. Structural biology of allergens. J. Allergy Clin. Immunol. 2000, 106, 228-238. [CrossRef] [PubMed]

29. Codex Alimentarius Commission. Alinorm 03/34: Joint FAO/WHO Food Standard Programme, Codex Alimentarius Commission, Twenty-Fifth Session, Rome, Italy, 30 June-5 July 2003. Appendix III, Guideline for the Conduct of Food Safety Assessment of Foods Derived from-DNA Plants and Appendix IV, Annex on the Assessment of Possible Allergenicity. 2003, pp. 47-60. Available online: http:/ / www.fao.org/3/y4800e/y4800e00.htm (accessed on 16 July 2016).

30. Colloms, S.D.; Sykora, P.; Szatmari, G.; Sherratt, D.J. Recombination at ColE1 cer requires the Escherichia coli xerC gene product, a member of the lambda integrase family of site-specific recombinases. J. Bacteriol. 1990, 172, 6973-6980. [CrossRef]

31. Alemayehu, D.; Casey, P.G.; Mcauliffe, O. Bacteriophages $\phi$ MR299-2 and $\phi N H-4$ Can Eliminate Pseudomonas aeruginosa in the Murine Lung and on Cystic Fibrosis Lung Airway Cells. MBio 2012, 3, e00029-12. [CrossRef]

32. Olsen, N.S.; Hendriksen, N.B.; Hansen, L.H.; Kot, W. A New High-Throughput Screening Method for Phages: Enabling Crude Isolation and Fast Identification of Diverse Phages with Therapeutic Potential. Phage 2020, 1, 137-148. [CrossRef]

33. Patpatia, S.; Yilmaz, O.; Ylänne, M.; Kiljunen, S. Isolation and Genomic Analysis of the Phage vB_PaeP_fHoPae04 Infecting Pseudomonas aeruginosa. Microbiol. Resour. Announc. 2021, 10, e0007621. [CrossRef] 
34. Magill, D.J.; Shaburova, O.V.; Chesnokova, E.N.; Pleteneva, E.A.; Krylov, V.N.; Kulakov, L.A. Complete nucleotide sequence of phiCHU: A Luz24likevirus infecting Pseudomonas aeruginosa and displaying a unique host range. FEMS Microbiol. Lett. 2015, 362, 2014-2016. [CrossRef] [PubMed]

35. Fong, S.A.; Drilling, A.; Morales, S.; Cornet, M.E.; Woodworth, B.A.; Fokkens, W.J.; Psaltis, A.; Vreugde, S.; Wormald, P.-J. Activity of Bacteriophages in Removing Biofilms of Pseudomonas aeruginosa Isolates from Chronic Rhinosinusitis Patients. Front. Cell. Infect. Microbiol. 2017, 7, 418. [CrossRef] [PubMed]

36. Alves, D.R.; Esteban, P.P.; Kot, W.; Bean, J.; Arnot, T.; Hansen, L.; Enright, M.; Jenkins, T. A novel bacteriophage cocktail reduces and dispersesPseudomonas aeruginosabiofilms under static and flow conditions. Microb. Biotechnol. 2015, 9, 61-74. [CrossRef] [PubMed]

37. Pires, D.P.; Kropinski, A.M.; Azeredo, J.; Sillankorva, S. Complete genome sequence of the Pseudomonas aeruginosa bacteriophage phiIBB-PAA2. Genome Announc. 2014, 2, 7-8. [CrossRef]

38. Zhang, L.; Le, S.; Lu, S.-G.; Yao, X.-Y.; Zhao, Y.; Wang, J.; Tan, Y.-L.; Hu, F.-Q.; Li, M. Isolation and identification a novel Pseudomonas aeruginosa phage PaP4. Microbiol. China 2013, 40, 609-616.

39. Alvi, I.A.; Asif, M.; Rehman, S.U. A single dose of a virulent bacteriophage vB PaeP-SaPL, rescues bacteremic mice infected with multi drug resistant Pseudomonas aeruginosa. Virus Res. 2021, 292, 198250. [CrossRef] [PubMed]

40. Campbell, R.A.; Farlow, J.; Freyberger, H.R.; He, Y.; Ward, A.M.; Ellison, D.W.; Getnet, D.; Swierczewski, B.E.; Nikolich, M.P.; Filippov, A.A. Genome Sequences of 17 Diverse Pseudomonas aeruginosa Phages. Microbiol. Resour. Announc. 2021, 10, e00031-21. [CrossRef]

41. Farlow, J.; Freyberger, H.R.; He, Y.; Ward, A.M.; Rutvisuttinunt, W.; Li, T.; Campbell, R.; Jacobs, A.C.; Nikolich, M.P.; Filippov, A.A. Complete Genome Sequences of 10 Phages Lytic against Multidrug-Resistant Pseudomonas aeruginosa. Microbiol. Resour. Announc. 2020, 9, e00503-20. [CrossRef]

42. Pleteneva, E.A.; Bourkaltseva, M.V.; Shaburova, O.V.; Krylov, S.V.; Pechnikova, E.V.; Sokolova, O.; Krylov, V.N. TL, the new bacteriophage of Pseudomonas aeruginosa and its application for the search of halo-producing bacteriophages. Russ. J. Genet. 2011, 47, 5-9. [CrossRef]

43. Latz, S.; Krüttgen, A.; Häfner, H.; Buhl, E.M.; Ritter, K.; Horz, H.-P. Differential Effect of Newly Isolated Phages Belonging to PB1-Like, phiKZ-Like and LUZ24-Like Viruses against Multi-Drug Resistant Pseudomonas aeruginosa under Varying Growth Conditions. Viruses 2017, 9, 315. [CrossRef] [PubMed]

44. Glukhov, A.S.; Krutilina, A.I.; Shlyapnikov, M.G.; Severinov, K.; Lavysh, D.; Kochetkov, V.V.; McGrath, J.W.; De Leeuwe, C.; Shaburova, O.V.; Krylov, V.N.; et al. Genomic Analysis of Pseudomonas putida Phage tf with Localized Single-Strand DNA Interruptions. PLoS ONE 2012, 7, e51163. [CrossRef]

45. Storey, N.; Rabiey, M.; Neuman, B.W.; Jackson, R.W.; Mulley, G. Genomic Characterisation of Mushroom Pathogenic Pseudomonads and Their Interaction with Bacteriophages. Viruses 2020, 12, 1286. [CrossRef]

46. Eller, M.R.; Salgado, R.L.; Vidigal, P.M.; Alves, M.P.; Dias, R.S.; de Oliveira, L.L.; da Silva, C.C.; de Carvalho, A.F.; De Paula, S.O. Complete Genome Sequence of the Pseudomonas fluorescens Bacteriophage UFV-P2. Genome Announc. 2013, 1, e00006-12. [CrossRef]

47. Reiter, W.D.; Palm, P.; Yeats, S. Transfer RNA genes frequently serve as integration sites for prokaryotic genetic elements. Nucleic Acids Res. 1989, 17, 5. [CrossRef]

48. Lei, X.; Wang, L.; Zhao, G.; Ding, X. Site-specificity of serine integrase demonstrated by the attB sequence preference of $\phi$ BT 1 integrase. FEBS Lett. 2018, 592, 1389-1399. [CrossRef] [PubMed]

49. Mohaisen, M.R.; McCarthy, A.J.; Adriaenssens, E.M.; Allison, H.E. The Site-Specific Recombination System of the Escherichia coli Bacteriophage Ф24B. Front. Microbiol. 2020, 11, 578056. [CrossRef] [PubMed]

50. Campbell, A.M. Chromosomal insertion sites for phages and plasmids. J. Bacteriol. 1992, 174, 7495-7499. [CrossRef] [PubMed]

51. Bailly-Bechet, M.; Vergassola, M.; Rocha, E. Causes for the intriguing presence of tRNAs in phages. Genome Res. 2007, 17, 1486-1495. [CrossRef]

52. Weiss, S.B.; Hsu, W.T.; Foft, J.W.; Scherberg, N.H. Transfer RNA coded by the T4 bacteriophage genome. Proc. Natl. Acad. Sci. USA 1968, 61, 114-121. [CrossRef] [PubMed]

53. Kihara, A.; Akiyama, Y.; Ito, K. Host regulation of lysogenic decision in bacteriophage: Transmembrane modulation of FtsH (HflB), the cII degrading protease, by HflKC (HflA). Proc. Natl. Acad. Sci. USA 1997, 94, 5544-5549. [CrossRef]

54. Rokney, A.; Kobiler, O.; Amir, A.; Court, D.L.; Stavans, J.; Adhya, S.; Oppenheim, A.B. Host responses influence on the induction of lambda prophage. Mol. Microbiol. 2008, 68, 29-36. [CrossRef]

55. Morello, E.; Saussereau, E.; Maura, D.; Huerre, M.; Touqui, L.; Debarbieux, L. Pulmonary Bacteriophage Therapy on Pseudomonas aeruginosa Cystic Fibrosis Strains: First Steps Towards Treatment and Prevention. PLoS ONE 2011, 6, e16963. [CrossRef] [PubMed]

56. Uchiyama, J.; Rashel, M.; Takemura, I.; Kato, S.-I.; Ujihara, T.; Muraoka, A.; Matsuzaki, S.; Daibata, M. Genetic characterization of Pseudomonas aeruginosa bacteriophage KPP10. Arch. Virol. 2012, 157, 733-738. [CrossRef] [PubMed]

57. Henry, M.; Lavigne, R.; Debarbieux, L. Predicting In Vivo Efficacy of Therapeutic Bacteriophages Used To Treat Pulmonary Infections. Antimicrob. Agents Chemother. 2013, 57, 5961-5968. [CrossRef] [PubMed]

58. Essoh, C.; Latino, L.; Midoux, C.; Blouin, Y.; Loukou, G.; Nguetta, S.-P.A.; Lathro, S.; Cablanmian, A.; Kouassi, A.K.; Vergnaud, G.; et al. Investigation of a Large Collection of Pseudomonas aeruginosa Bacteriophages Collected from a Single Environmental Source in Abidjan, Côte d'Ivoire. PLoS ONE 2015, 10, e0130548. [CrossRef] 
59. Coleman, S.; Yao, T.; Nguyen, T.V.P.; Golding, I.; Igoshin, O. Bacteriophage self-counting in the presence of viral replication. bioRxiv 2021. [CrossRef]

60. Zhao, X.; Chen, C.; Shen, W.; Huang, G.; Le, S.; Lu, S.; Li, M.; Zhao, Y.; Wang, J.; Rao, X.; et al. Global Transcriptomic Analysis of Interactions between Pseudomonas aeruginosa and Bacteriophage PaP3. Sci. Rep. 2016, 6, 19237. [CrossRef]

61. Chen, J.; Quiles-Puchalt, N.; Chiang, Y.N.; Bacigalupe, R.; Fillol-Salom, A.; Chee, M.S.J.; Fitzgerald, J.R.; Penadés, J.R. Genome hypermobility by lateral transduction. Science 2018, 362, 207-212. [CrossRef]

62. Garneau, J.R.; Depardieu, F.; Fortier, L.-C.; Bikard, D.; Monot, M. PhageTerm: A tool for fast and accurate determination of phage termini and packaging mechanism using next-generation sequencing data. Sci. Rep. 2017, 7, 8292. [CrossRef]

63. Casjens, S. Prophages and bacterial genomics: What have we learned so far? Mol. Microbiol. 2003, 49, 277-300. [CrossRef]

64. Eller, M.R.; Vidigal, P.M.P.; Salgado, R.L.; Alves, M.P.; Dias, R.S.; da Silva, C.C.; de Carvalho, A.F.; Kropinski, A.; O De Paula, S. UFV-P2 as a member of the Luz24likevirus genus: A new overview on comparative functional genome analyses of the LUZ24-like phages. BMC Genom. 2014, 15, 7. [CrossRef] [PubMed]

65. Savalia, D.; Westblade, L.F.; Goel, M.; Florens, L.; Kemp, P.; Akulenko, N.; Pavlova, O.; Padovan, J.C.; Chait, B.T.; Washburn, M.; et al. Genomic and Proteomic Analysis of phiEco32, a Novel Escherichia coli Bacteriophage. J. Mol. Biol. 2008, 377, 774-789. [CrossRef] [PubMed]

66. Schneider, C.L. Bacteriophage-Mediated Horizontal Gene Transfer: Transduction. In Bacteriophages; Springer: Cham, Switzerland, 2017; pp. 1-42. [CrossRef]

67. Guttman, B.; Raya, R.; Kutter, E. Basic phage biology. In Bacteriophages; CRC Press: Boca Raton, FL, USA, 2005.

68. FAO; WHO. Evaluation of Allergenicity of Genetically Modified Foods Derived from Biotechnology; FAO: Rome, Italy, 2001.

69. Curtright, A.J.; Abedon, S.T. Phage Therapy: Emergent Property Pharmacology. J. Bioanal. Biomed. 2012, S6, 2. [CrossRef]

70. Petrovic Fabijan, A.; Lin, R.C.Y.; Ho, J.; Maddocks, S.; Ben Zakour, N.L.; Iredell, J.R.; Westmead Bacteriophage Therapy Team. Safety of bacteriophage therapy in severe Staphylococcus aureus infection. Nat. Microbiol. 2020, 5, 465-472. [CrossRef] 